\title{
Resyllabification of laterals in Brazilian Portuguese
}

\author{
GiSELA COLLISCHONN \\ CRISTINE COSTA
}

\begin{abstract}
Lateral sounds in Brazilian Portuguese have received some amount of attention, both from quantitative studies and from dialectology. In this paper we will study the variable pronunciation of $\mathrm{M} /$ as either consonantal or vocalic, relating it to the possibility of resyllabification across different types of prosodic boundaries. We examine the patterns of vocalization/non-vocalization in a sample of speakers from Porto Alegre, the capital of the southern Brazilian state of Rio Grande do Sul, using quantitative analysis. Our results provide empirical support for the role of prosodic constituents in Brazilian Portuguese phonology.
\end{abstract}

\section{Introduction}

In Brazilian Portuguese (BP) the underlying coda lateral is realized variably as [1], [ł] or [w], dialectological and sociolinguistic data showing that the three variants occur postvocally and that the choice between the various realizations is in part determined by sociolinguistic conditioning (see section 2 , below). Such data demonstrate that a change is in progress and that the most advanced dialects in the change are those presenting mainly the [w] variant, this view being based on the fact that speakers from urban centers show the highest values for the [w] variant (such speakers also being innovating with respect to other sociolinguistic variables) and that, in general, in all the varieties studied older speakers use the [1] and [ł] variants more frequently than younger people.

The idea that the underlying segment of these variants is the alveolar lateral is supported by the following alternations:

(1)

Underived word

papel $[\mathrm{\exists}] \sim \mathrm{w}]$ paper papelada

azul blue azulado

sol sun solaço

fuzil gun fuzilar

sal salt saleiro

nível level nivelar

$\begin{array}{lll}\begin{array}{ll}\text { Affixed word } \\ \text { papelada }\end{array} & {[1]} & \begin{array}{l}\text { a lot of paper } \\ \text { bluish }\end{array} \\ \text { azulado } & & \text { bright sunlight } \\ \text { solaço } & \text { to execute } \\ \text { fuzilar } & \text { saltcellar } \\ \text { saleiro } & \text { to level } \\ \text { nivelar } & \end{array}$

ISSN 1645-4537 
Evidence of this kind is missing for root-internal postvocalic laterals, as in bolsa ['bowsa] "purse". That there are varieties which still have the alveolar laterals in coda position, however, can be considered as evidence for $/ 1 /$ as the underlying form, also root-internally. ${ }^{1}$

The three variants may be identified with three derivational stages. The [ł] variant is derived from the alveolar lateral segment by one rule, while another rule targets this derived velarized lateral to produce the vocalic variant - the two rules appertaining to a process of lenition which results in less articulatory effort. This process is shown in the diagram (2) below (based on Walsh, 1997) in which every lateral segment has a double coronal-dorsal articulation.

[1]

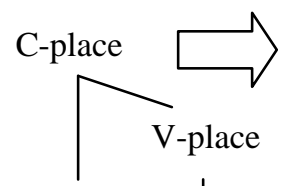

Coronal

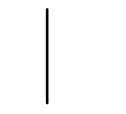

Dorsal [ł]

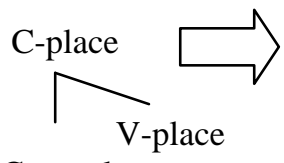
Coronal

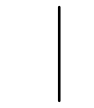

Dorsal<smiles>C=C</smiles>

[dorsal] [w]

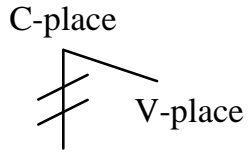

Coronal Dorsal Labial

\footnotetext{
${ }^{1}$ We do not exclude the possibility that some dialects may have had their underlying representations restructured, but literature on BP phonology is lacking on this issue. Evidence put forward in Oliveira and Cristófaro-Silva (2002) concerning the articulation of "r" sounds after underlying /l/s (e.g. bilro "kind of lace"), in the dialect of Minas Gerais, shows that a restructuring may have occurred, at least in the younger generations. However, we do not believe that the glide has generalized as the underying form in the dialect we are analyzing here. There are some other correspondences in BP, such as mau - maldade ("wicked" - "wickedness") and céu - celeste ("heaven" - "heavenly"), which however cannot be related to the present analysis, since they are relicts of another process, intervocallic /1/ deletion in Old Portuguese, a process we will not be concerned with here. Likewise, we will not be concerned with the realization of plurals like papéis "papers", azuis "blue, pl.”.
} 
Both the alveolar and the velarized lateral have a primary Coronal node and a secondary Dorsal node. The velarized lateral has, however, an additional [dorsal] feature linked to the Dorsal node, which reinforces the dorsal articulation of this kind of segment. The loss of the Coronal node leads to the loss of laterality, since, for Walsh (1997), what distinguishes a segment as lateral is exactly this double coronal-dorsal specification. So the loss of the Coronal node produces a vocalic segment, here identified as [w]. ${ }^{2}$

BP like other Romance languages shows resyllabification at the post-lexical level. Word-final /1/s are resyllabified with a following onsetless syllable, as is shown by the examples below, taken from our corpus:

(3)

$$
\begin{array}{ll}
\text { O Brasi[l a]umentou... } & \text { 'Brazil has increased...' } \\
\text {...pessoa[lã]ntigo... } & ‘ \text {...older people...' } \\
\text {...futebo[lo]u vôlei... } & ' \text {...football or volleyball...' }
\end{array}
$$

The interpretation in Monaretto, Quednau and Hora (1999) of the kind of data in (3) is as follows: the rules of velarization and vocalization are post-lexical. Postlexically, resyllabification bleeds velarization and vocalization. This explains why speakers who normally have only the velarized or the vocalic variant in coda show the alveolar variant in word-final context when followed by a vowel. This seems to be the case for the variety of BP spoken in Porto Alegre, the capital of the southernmost Brazilian state of Rio Grande do Sul (RGS), which shows the highest value for vocalization of all the southern Brazilian communities studied.

In a quantitative analysis where vocalization was considered the dependent variable, Quednau (1993) found that:

(a) before another consonant (tal lugar "that place"), vocalization is significantly favored;

(b) before a pause (sul\# "south"), vocalization is relatively favored;

(c) before a vowel (carnaval é, "carnival is"), vocalization is disfavored.

There seems to be a negative correlation between resyllabification and the vocalization of laterals, although this does not mean that vocalization never happens when an onsetless syllable follows - e.g. the rate of vocalization in context $(4 \mathrm{c})$ is low but is not zero. ${ }^{3}$

\footnotetext{
${ }^{2}$ In contrast to other geometrical representations, such as that proposed in Clements and Hume (1995), the autosegmental representation above does not imply that velarization necessarily precedes vocalization

${ }^{3}$ In Quednau (1993), relative weights obtained for the contexts presented in (4) are following: (a) before another consonant $-0,65$; (b) before a pause $-0,57$; (c) before another vowel $-0,22 .^{3}$
} 
The possibility of resyllabification is also not categorical but depends on the boundary that is being crossed. According to Nespor and Vogel (1986), resyllabification does apply within a phrasal domain defined language particularly. Thus, it is important to establish in which domains resyllabification is possible in BP in order to see whether there is a correlation between vocalization tokens and the possibility of resyllabification.

Bisol (1999b) presents evidence from a corpus of educated speech (Projeto NURC), that resyllabification of $/ \mathrm{r} /$ and /s/ happens across phonological phrase boundaries in BP.

$$
\begin{array}{ll}
\text {...para da }[\Gamma \mathrm{e}] \mathrm{sclarecimentos} & \text { '...in order to give explanations' } \\
\text {...mas faze }[\Gamma \mathrm{u}] \mathrm{ma} \text { análise } & \text { '...but to make an analysis' } \\
\text {...fi[zo]strês anos } & \text { '...(I) did the three years' }
\end{array}
$$

(from Bisol, 1999b: 722)

The first two dialects in (5) above are from Rio de Janeiro and Recife, respectively, and in these dialects the consonantal allophone $[\Gamma]$ is usually allowed only in the syllable onset position. The phonetic realization of the consonant shows that it is resyllabified as the initial vowel of the following word. In the third example, from an informant from Salvador, the allophonic evidence for resyllabification is not so straightforward because the alveolar fricative may appear in coda in that variety, nevertheless it appears that the fricative is resyllabified because it is not devoiced.

Brescancini (2002) has shown evidence of word-final fricative resyllabification in the variety of BP spoken on the island of Florianópolis in the southern Brazilian state of Santa Catarina, this author having found that the fricative is systematically non-palatalized when word-final and immediately followed by a vowel though it is usually palatalized in other contexts. The examples given by Brescancini (2002) show that resyllabification of the fricative is not restricted to smaller prosodic units.

In an experiment conducted with six informants from the State of São Paulo, Tenani (2002) also observed that resyllabification of $/ \mathrm{r} /$ and $/ \mathrm{s} /$ is not blocked by higher prosodic boundaries such as those between Intonational phrases and Utterances.

Bisol (1999, pp. 240-241) and Tenani (2002) also state that for vocalic sandhi the domain seems to be larger than the phonological phrase. Tenani (2002) also showed that haplology is not blocked by higher prosodic boundaries in PB, although the rate of application decreases when the boundaries of higher domains are involved.

There are a number of issues related to the possibility of resyllabification that neither of the aforementioned analyses of variation in laterals has addressed and, furthermore, the research that has examined the blocking effect of higher prosodic boundaries has never taken the resyllabification of /1/ into 
account. Because of this we have searched for data that can shed some light on the question as to whether or not different prosodic boundaries allow the resyllabification of the lateral and as to whether there is free variation or is the realization of word-final laterals dependent on the adequate definition of the contexts that admit resyllabification.

In the study reported in this paper we investigated in precisely what circumstances vocalizing speakers show alveolar /l/ in word-final position. In order to avoid too many external variables, we chose a fairly homogeneous sample of spoken BP data from Porto Alegre, a community with high values of vocalization.

Resyllabification is a structural feature that is reflected in the speech sign through a series of cues, the cue we considered being the phonetic properties of the resyllabified consonant. The appearance of a semivowel or a velarized lateral points to the absence of resyllabification, since these are not admissible onset allophones. On the other hand, the occurrence of an alveolar lateral does not necessarily indicate resyllabification, since alveolar laterals are attested in the coda in several of the dialects previously studied (see following section). Nonetheless, since our data came from a dialect in which the values of vocalization in the coda are very high and where the values for alveolar laterals in the coda are near to non-existent, we assumed that the presence of a word final alveolar lateral indicates that this segment was resyllabified. ${ }^{4}$

In the following section, we present sociolinguistic and dialectological studies that addressed variable laterals in Brazilian Portuguese. Thus, even though our study focuses on just one sample of this Portuguese dialect, it is possible for the reader to place this variety among the other varieties of Portuguese spoken in southern Brazil with respect to the realization of post-vocalic laterals.

\footnotetext{
${ }^{4}$ A rather different possibility could be considered here: that the lateral is vocalized in the lexical phonology of BP and, afterwards, the resulting glide is resyllabified as an onset of a following vowel initial word. In BP phonology evidences on this issue are not easy to get, since facts are obscured by a series of postlexical vocalic sandhi processes. However, we believe that this alternative is not really available. In BP phonology, onsets constituted only by a glide are marginal; they emerge only in word-internal position, as hiathus resolution. They never emerge in absolute initial position. In postlexical phonology, in vocalic sandhi, glides may constitute simple onsets, optionally, in sequences like veio aqui ['vej.wa.'ki] "came here" balaio azul [ba'.laj.wa.'zuw] "blue basket". However, this possibility of resyllabifying as an onset seems very limited even for true word final glides; see for example sequences like seu amigo "his friend", which gives ['sew.a.'mi.gu] rather than ['se.wa.'mi.gu]. Another reason is that one can utter the syllables of a sequence like papel amarelo "yellow paper" in slow speech as [pa $-\mathrm{p} \varepsilon-1 \mathrm{a}-\mathrm{ma}-\mathrm{r} \varepsilon-\mathrm{lv}$ ] but not as [pa $-\mathrm{p} \varepsilon-\mathrm{wa}-\mathrm{ma}-\mathrm{r} \varepsilon-\mathrm{lv}]$. Finally, we have observed in our data that sometimes vocalization may be followed by an alveolar lateral, for example hospita[w] ]existe... "(the) "(the) hospital exists..." This shows that resyllabification is freely available for consonants but not for vowels.
} 


\section{The linguistic variable under study}

To present the sociolinguistic context in which the variety of BP described in this paper is set we need to outline the results of some previous quantitative and dialectological studies relevant to our research.

In a comparative study of the Portuguese spoken in the major Brazilian cities (Recife, Salvador, Rio de Janeiro, São Paulo and Porto Alegre), Callou et al. (2002) found that $/ \mathrm{l} /$ is vocalized throughout Brazil and cannot be considered a feature of the speech of less educated people only and that, almost exclusively, Porto Alegre presents the velar or alveolar variants while the other cities have predominantly vocalized laterals in codas. The data of Callou et al. (2002) came from a corpus collected in the 1970's and show that a rapid change towards vocalization was occurring in Porto Alegre. This was corroborated by later researches (Quednau, 1993; Tasca, 1999), although these later studies also show that alveolar and velarized laterals were still alive in the smaller towns and the rural area of the southern Brazilian states of Santa Catarina and Rio Grande do Sul (of which Porto Alegre is the capital) at the time of the studies.

Quednau (1993) and Tasca (1999) quantitatively analyzed the variable post-vocalic /1/ in spoken Portuguese in the state of Rio Grande do Sul and found that the ethnic or geographical group of the speaker was the most significant variable in their studies.

Quednau (1993) analyzed vocalization in samples of speech collected in the middle of the 1980 's ${ }^{5}$ from the metropolitan area of the city of Porto Alegre (founded by Portuguese speakers), the medium-sized town of Santana do Livramento on the border between Uruguay and Brazil (an area of both Spanish and Portuguese influence) and the small towns of Taquara (founded by German speakers) and Monte Bérico (founded by Italian speakers) and found that Porto Alegre the probability of use of [w] is very high while in the German and Italian settlements and the border areas the probability sinks to about 0.30 , in other words the vocalization of post-vocalic / / / in Porto Alegre is nearly categorical while in the other areas the other variables are still preserved.

Tasca (1999) analyzed the preservation of the post-vocalic lateral in samples of speech collected at the end of the 1980's in metropolitan Porto Alegre, the town of São Borja on the border between Argentina and Brazil (another area of both Spanish and Portuguese influence) and the small towns of Flores da Cunha (founded by Italian speakers) and Panambi (founded in the northwest of RGS by German speakers but later than Taquara) and observed that the preservation of the alveolar [1] in the coda of speakers from Panambi and Flores da Cunha is more extensive than the velarized lateral and that the use of the $[\mathrm{w}]$ variant is very low, although among women and more educated

\footnotetext{
5 The informants of the Italian and German settlement area were bilinguals.
} 
speakers there was a hint of a change towards the more innovative forms [ł] and $[\mathrm{w}]$.

Espiga (2001) studied l-variability in an area in the south of Rio Grande do Sul near the Uruguayan border where the alveolar variant is still predominant and found that change was occurring with younger people being more likely to choose innovating forms.

The research described above suggests that there is ongoing dialect leveling involving / $/$ / usage and that Porto Alegre appears to be the irradiating center. ${ }^{6}$

Variability in post-vocalic laterals is also described in the Linguistic and Ethnographic Atlas of Southern Brazilian Portuguese (Atlas Lingüístico-Etnográfico da Região Sul do Brasil (ALERS), Altenhofen et al., 2002), a large-scale survey corpus of variation in the lexical, phonological, morphological and grammatical levels of southern BP in the states of Paraná, Santa Catarina and Rio Grande do Sul. The ALERS data collection supports the results of the research described above and contains maps showing that in Rio Grande do Sul the alveolar variant is preserved in the syllabic coda, although this variant begins to lose strength as one moves north; with the alveolar lateral being largely substituted by other variants, especially the velarized alveolar, in Santa Catarina and by both the velarized and vocalized variant (or even by rhotics such as the flap or the retroflex tap) in Paraná.

These studies agree that while ethnic or geographical groups (i.e. areas colonized by Italian and German settlers and the area of the Hispanic border) still have an alveolar or velarized lateral in their coda, vocalization is very frequent in metropolitan areas, and that there is a general change in progress from the alveolar lateral to the vocalic segment via the velarized lateral and that this innovation appears to show hierarchical diffusion in that it is irradiating from large cities to large towns, small towns, etc.

Turning to the internal factors that contribute to the probability of occurrence of vocalization or velarization, statistical studies have shown that a following pause or a consonant-initial word favors vocalization while a following vowel-initial word disfavors it and that when resyllabification is possible it will take place, blocking vocalization or velarization. Quednau (1993) has also found that preceding mid or low vowels favor vocalization while preceding high vowels disfavor it, and that a following consonant with tongue articulation favors vocalization. Both Quednau (1993) and Tasca (1999) have found that variation is also conditioned by stress, however the conditioning factors found in each analysis were not the same.

\footnotetext{
${ }^{6}$ The results in Dal Mago (1998) suggest that same process seems to be happening in the neighboring state of Santa Catarina, in this case with Florianópolis (the state capital) as the irradiating center.
} 


\section{Phonological background}

As was discussed in the Introduction, the aim of our research was to establish the upper prosodic limits within which resyllabification may happen. Our analysis is based on the Prosodic Phonology theory proposed by Nespor and Vogel (1986) and elaborated by Hayes (1989), according to which phrasal phonology is governed by a hierarchical constituent structure which is distinct from syntactic structure, although syntax does play a crucial role in determining the form of the constituents (other possible factors include focus, speaking rate and length of the constituents). The following constituents are generally recognized:

(6)

$\begin{array}{ll}\text { U } & \text { Utterance } \\ \left.\right|_{\omega} & \text { Intonational phrase } \\ F_{\sigma} & \text { Phonological phrase } \\ \sigma & \text { Foot } \\ & \text { Syllable }\end{array}$

There are three ways in which rules may make reference to these constituents: (a) rules may be bounded by a particular domain, that is, the rule may only apply if the elements in its structural description appear within the same domain; (b) rules may apply to elements at the edges of a particular domain; (c) rules may refer to the juncture of two domains within a larger domain. Later in this paper we will show that resyllabification is blocked across the prosodic domain boundaries I and U. As we have mentioned earlier, there are a number of sandhi phenomena in BP that freely apply across I and U boundaries. Nevertheless, our systematic study, based on a sample of speakers, shows that the I and $\mathrm{U}$ domain boundaries tend towards constraining or blocking resyllabification.

To clarify our parsings in the data analysis, let us briefly review the definitions of the Phonological Phrase, the Intonational Phrase and the Utterance. Although we are not concerned with the smaller prosodic domains because they play no crucial role in our analysis, it should be mentioned that, based on work by Vigário (2003), we assume that proclitics are adjoined to the follow- 
ing prosodic word, yielding a recursive where one prosodic word is embedded in a higher-order prosodic word. ${ }^{7}$

In our analysis, a Phonological Phrase is formed according to the rules of the X-bar system of syntax (Hayes, 1989, p. 214), thus:

$$
\text { In }\left[\ldots X^{0} Y^{\prime}, \ldots\right]_{X},
$$

a. $\left[\ldots X^{0}\right]$ obligatorily forms a $\phi$, and

b. $\left[\ldots \mathrm{X}^{0} \mathrm{Y}^{\prime}\right.$ '] optionally forms a $\phi$ if $\mathrm{Y}^{\prime}$ ' does not branch.

We consider that $Y^{\prime \prime}$ does branch when it is comprised of two prosodic words but does not branch when it contains a recursive prosodic word resulting from proclitic adjunction. So, for instance, the sentence Até pensava que a lua pendurada no céu fosse um pandeiro de prata " $(\mathrm{He})$ even thought that the moon hanging from the sky was a silver tambourine" contains the $\phi s$ as indicated in (8) below:

a. $\quad[\text { até })_{\omega}$ (pensava $\left.\left.\left.)_{\omega}\right]_{\phi}\left[(\text { que (a (lua })_{\omega}\right)_{\omega}\right)_{\omega}\right]_{\phi}$

b. $\left[(\text { pendurada })_{\omega}\right]_{\phi}\left[\left(\text { no }(\text { céu })_{\omega}\right)_{\omega}\right]_{\phi}$

c. $\left.\left[(\text { fosse })_{\omega}\right]_{\phi}[(\text { um (pandeiro }))_{\omega}\right]_{\phi}\left[\left(\text { de }(\text { prata })_{\omega}\right)_{\omega}\right]_{\phi}$

The parentheses show the embedded structure. According to b., the $\phi s$ in the first and the second line could be structured as below, since the complement of $\mathrm{X}^{0}$ is not branching.

\section{(9)}

a. $\left[(\text { até })_{\omega} \text { (pensava) }\right)_{\omega}$ (que (a (lua $\left.\left.\left.)_{\omega}\right)_{\omega}\right)_{\omega}\right]_{\phi}$

b. $\left[(\text { pendurada })_{\omega}\left(\text { no }(\text { céu })_{\omega}\right)_{\omega}\right]_{\phi}$

In the third line, the noun phrase (NP) um pandeiro de prata may form one phonological phrase. However, this option is not available for the whole verb phrase (VP) fosse um pandeiro de prata, since the complement of the verb consists of two prosodic words. In our analysis, wherever the option exists of adjoining a non-branching complement to a $\phi$-phrases this is the option taken.

We assume that each member of a compound forms a prosodic word by itself and, therefore, the boundary between them is analyzed as internal to the phonological phrase. However, our analysis does not treat compounds as ordinary phonological phrases, since in Vigário (2003) it is argued that in

\footnotetext{
${ }^{7}$ Vigário (2003) has proposed that structure for European Portuguese. There is also evidence for BP that clitics do not behave like ordinary pretonic syllables. Bisol (1999) has interpreted this evidence as supporting the clitic group analysis. For the sake of the present analysis, the correct interpretation of the behavior of clitics is not at issue and we adopt the representation in Vigário (2003).
} 
European Portuguese compounds form a recurrent structure based on the special behavior of their internal boundaries in regard to several postlexical rules. Although we do not have sufficient evidence for this recurrent structure in BP, we include it in our quantitative analysis (described below) in order to check if compounds also behavior in this way in BP.

The definition of Intonational Phrase is not so straightforward, since the rules deriving I-phrases vary in their application. What is certain is that some syntactic boundaries correspond to edges of I-phrases; the edges of parentheticals, vocatives and appositives; the edges of topicalized clauses or constituents; or the edges of non-restrictive relative clauses. The boundaries between subject and verb phrases and the boundaries between the main clause and the embedded clause are also candidates for I-phrase edges. However, this is not necessarily so since the need to produce I-phrases of approximately equal length can bring about the grouping of syntactically independent phrases or the partitioning of excessively long phrases. So, in parsing our I-phrase data we have had to combine syntactic, phonetic and pragmatic information.

According to Tenani (2002), I-phrase edges may be indicated by pauses but not necessarily so, a pause being more frequently found when the first I-phrase is a moved constituent. Another cue generally associated with the pause, is a boundary tone. Other phonetic cues such as variation in register, fundamental frequency $\left(\mathrm{F}_{0}\right)$ or speech velocity are more frequently found when two clauses have a syntactic-semantic relationship that is not expressed by a connective.

In our work we use an impressionistic parsing of stretches of speech in Intonational Phrases, based on the parameters given above. We consider that pauses of hesitation, false starts and corrections produce Intonational phrase edges.

The definition of Utterance takes into account not only syntactic information but also semantic and phonetic information. An Utterance normally corresponds to a full sentence, although two short sentences can constitute one Utterance when there is a strong semantic relationship between them. According to Hayes (1989, p. 219) an Utterance "comprises a maximal sequence between phonetic structural pauses", where 'phonetic' refers to "pauses that are not only heard by native listeners but that involve the actual cessation of speaking', and 'structural' does not refer to hesitation pauses and other performance phenomena.

With these definitions in mind we can formulate a series of questions, thus:

(10)

What happens when the context for resyllabification is met

(A) on a compound-internal boundary?

(B) on a boundary between prosodic words in the same $\phi$ ? 
(C) on a boundary between two phonological phrases?

(D) on a boundary between two intonational phrases?

(E) on a boundary between two utterances?

Before explaining other methodological issues, let us address some of the difficulties of our study. Most analyses of prosodic phrasing phenomena have been based on experiments where speakers read sentences specially designed for the purpose of the experiment, such experiments not only having the advantage of yielding input parsing of prosodic constituents but also provide some control over performance variability. The purpose of our experiments was to investigate prosodic constituents using quantitative variationist methodology, or else to use variationist methodology to study prosodic phrasing. Since our data consisted of casual speech that was not specifically collected for the purpose of the our analysis, we sometimes have had to be impressionistic when interpreting the parsing of prosodic constituents. The other shortcoming of casual speech data is that we will not be able to make comparisons between the same number of tokens for each of the contexts mentioned in (10). However, this may be overcome by using the VARBRUL programs, which are designed to handle unbalanced data of the kind that occur in variation studies. ${ }^{8}$ We feel that the use of casual speech data did not compromise our approach, all the more because there are several implied advantages in the use of casual speech data, the most obvious advantages being the focus on actual language and the large amount of data obtained from a large group of speakers, which may reveal some unexpected patterns. We therefore think that the type of research described in this paper is complementary to the better controlled experiments published by other workers.

Another issue is why resyllabification should be understood as 'resyllabification' and not as 'ambisyllabification' or as the post-lexical syllabification of a former 'extraprosodic' consonant. Since resyllabification is structure-changing and requires extrinsic ordering in the postlexical component, would it not be better to replace this analysis with an analysis that resorts to "extraprosodicity' or 'ambisillabicity'? Peperkamp (1997) argues against the use of extraprosodic and ambisyllabic analyses in languages such as Italian and Spanish, the arguments used by Peperkamp also being valid with regard to the prosodic status of coda /1/ in BP because: (1) codas with /1/ are lexically wellformed in Portuguese and may surface in some varieties; (2) if final /1/s were not syllabified, they should be dropped before a consonant-initial word, due to Stray Erasure (this deletion of $/ 1 /$ is not attested in BP); (3) final /l/s count for the purpose of stress assignment because they are moraic (Wetzels, 1997); and if /// was not syllabified as a coda at the (lexical) level at which stress is accounted for it would be predicted that it is not relevant for the stress algorithm.

\footnotetext{
${ }^{8}$ VARBRUL is a package of programs developed by David Sankoff (Sankoff, 1988),
} extensively used in variationist research. 
The ambisyllabic hypothesis is a little more difficult to dismiss; indeed for other consonants, like final /s/, we have evidence for ambisyllabicity, since it may form the onset of a following vowel-initial word while it causes at the same time the (postlexical) diphtongization of the preceding vowel, as for instance in sequences like n[ojza]gora... "we now...", fre[gejzän]tigo "long-standing customer". Unfortunately, there are not enough acoustic descriptions of intervocalic and resyllabified /1/s in BP which could help to eliminate the ambisyllabicity hypothesis. For theoretical reasons, we prefer the more restricted hypothesis of resyllabification, leaving this issue open for future research.

\section{Methodology}

\subsection{Data}

Our data came from an archive of recordings gathered between 1998 and 2000 by the VARSUL PROJECT, a corpus of spoken data collected with the aim of studying regional dialects in southern Brazil. ${ }^{9}$ The corpus consists of sociolinguistic interviews of about 60 minutes, recorded in the capitals of three southern Brazilian states, Paraná, Santa Catarina and Rio Grande do Sul, as well as in some other towns, particularly those that are known for their predominant German and Italian immigration. The samples are stratified according to age, sex and educational level.

Our sample consisted of 12 interviews with highly educated informants (possessing a university degree or diploma) living in Porto Alegre, the table below showing the composition of our social cells.

(11)

\begin{tabular}{|c|c|c|c|c|c|c|}
\hline \multirow[b]{3}{*}{ Sex } & \multicolumn{6}{|c|}{ Age group (approximate age in years) } \\
\hline & \multicolumn{2}{|c|}{20 to 30} & \multicolumn{2}{|c|}{30 to 60} & \multicolumn{2}{|c|}{60 to 75} \\
\hline & Informant & Age in years & Informant & Age in years & Informant & Age in years \\
\hline Male & 1 & 25 & 3 & 54 & 5 & 70 \\
\hline Male & 2 & 31 & 4 & 59 & 6 & 72 \\
\hline Female & 7 & 28 & 9 & 34 & 11 & 65 \\
\hline Female & 8 & 31 & 10 & 53 & 12 & 76 \\
\hline
\end{tabular}

In previous research by one of the authors of this paper (Costa, 2003), the overall application of vocalization in the speech of these informants was cal-

\footnotetext{
${ }^{9}$ The previously mentioned researches of Dal Mago (1998) and Tasca (1999) were based on this corpus.
} 
culated, considering not only social variables such as sex and age but also the following linguistic factor groups: ${ }^{10}$

(12)

\begin{tabular}{llll}
\hline Factor group & Individual factors & \multicolumn{1}{c}{ Example } & \multicolumn{1}{c}{ Translation } \\
\hline Dependent & Vocalization & ca[w]ço & (I) wear \\
variable & Non-vocalization ${ }^{11}$ & ca[ł]ma or ca[1]ma & calm \\
\hline Preceding & High non-back vowel & filme & film \\
environment & Mid non-back vowel & lamentavelmente & regrettably \\
& Low vowel & alguma & some \\
& Mid back vowel & bolsa & purse \\
& High back vowel & cultura & culture \\
\hline Following & Labial stop & albergue & hostel \\
environment & Labial nasal & alma & soul \\
& Labiodental fricative & envolvida & involved \\
& Alveolar fricative & hospitalzinho & small hospital \\
& Alveolar stop & faculdade & faculty \\
& Alveolar nasal & El Niño & El Niño (climate) \\
& Palatal fricative & nostalgia & nostalgia \\
& Velar stop & folgado & loose \\
& Pause & & \\
& \# plus vowel & qual é... & which is... \\
\hline Stress & Stressed & aluguel & rent \\
& Prestressed & calçada & sidewalk \\
& Posstressed & horrível & horrible \\
& Monosyllable & mal & bad \\
\hline Morphological & Root interior & calça & trousers \\
boundaries & Beforemorpheme & & \\
& boundary & oralmente & orally \\
& Before word boundary & Portugal & Portugal \\
& Suffix final & mundial & world-wide \\
\hline Word class & Name & & \\
& Verb & & \\
& Other & & \\
\hline & & & \\
& & & \\
& & & \\
& & & \\
& & & \\
& & & \\
& & & \\
& & & \\
& & & \\
& & & \\
& &
\end{tabular}

The VARBRUL program analysis of 1742 tokens revealed that the overall likelihood for speakers to choose the vocalized variant is very high, reaching 98. ${ }^{12}$ The step-up and step down analysis selected the factor groups age, fol-

10 The factors shown in any given factor group are the end result of the variable rule analysis, where many initial factors have been combined.

11 This factor could include, apart from [ $¥]$, also the alveolar variant [1]. However, the showing up of this variant was insignificant in this sample.

12 The values are as usually given in VARBRUL weights. A value above 0.50 indicates that there is a factor which favors the application of the rule, while a value below 
lowing phonological environment and preceding phonological environment as being significant. The linguistic factors that mostly favor vocalization are: ${ }^{13}$

(13)

a) $/ 1 /$ is followed by a labiodental fricative (.84);

b) $/ 1 /$ is followed by a velar stop or an alveolar fricative (.75);

c) $/ 1 /$ is preceded by a low vowel (.75).

d) $/ 1 /$ is followed by an alveolar stop (.58);

The factors that mostly disfavor vocalization are:

(14)

a) $/ 1 /$ is followed by a word boundary followed by a vowel initial word (.10);

b) $/ 1 /$ is followed by a palatal fricative (.20);

c) $/ 1 /$ is followed by a pause (.38);

d) $/ 1 /$ is preceded by a high non-back vowel (.26);

e) $/ 1 /$ is preceded by a mid back vowel (.25);

f) $/ 1 /$ is preceded by a mid non-back vowel (.16).

The following graph shows the correlation between age and rate of vocalization. Informants are ordered on the horizontal line according to age. The values indicate the contribution to the probability of vocalization of each individual (not the percentages of vocalization). The graph reveals a steep increase in the use of vocalization in the younger age groups, with older informants showing less vocalization.

0.50 indicates a factor which disfavors the rule, and a value similar to 0.50 indicates a factor which has essentially no effect on the rule.

13 The values in parentheses show the relative weight obtained for each factor in the analysis. 
(17)

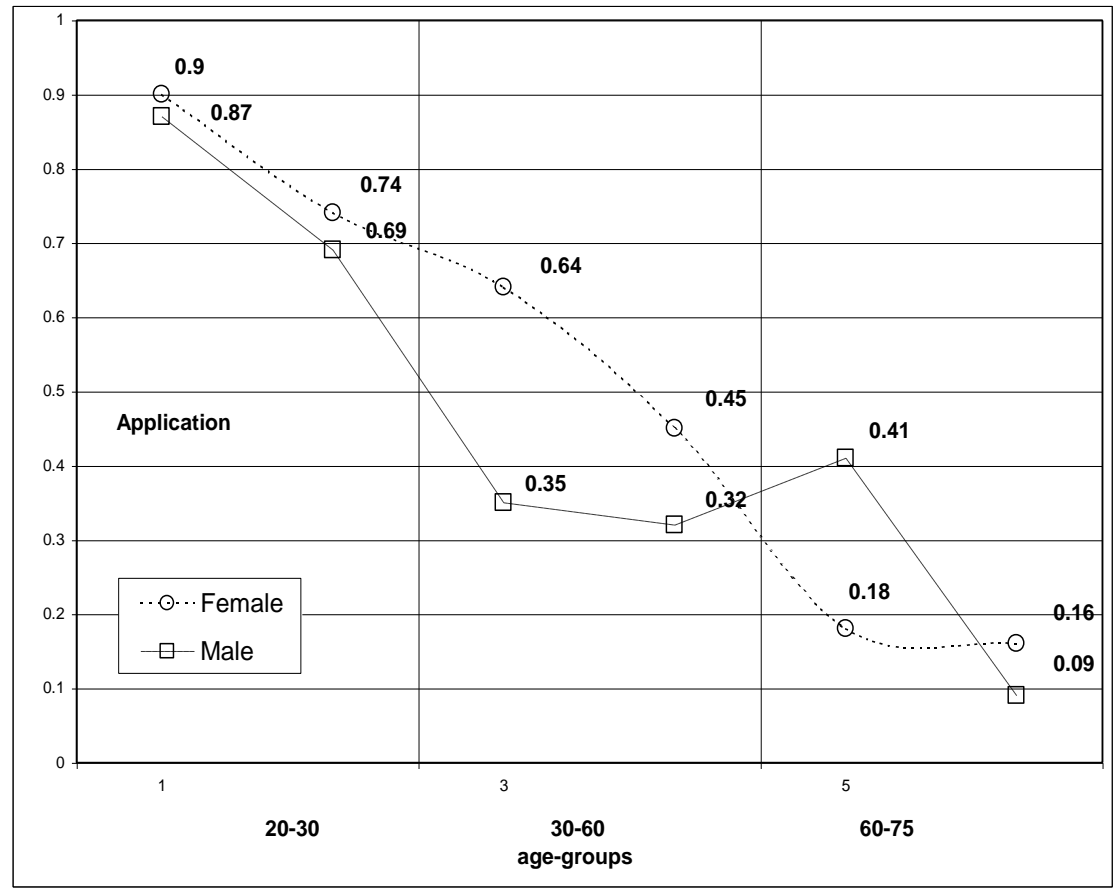

The graph (17) also shows that the rate of vocalization is very high, almost categorical for some of the younger informants of the sample. We also found that a word boundary followed by a vowel initial word disfavors vocalization because of the possibility of resyllabification. Even those informants that normally showed high rates of vocalization showed lesser vocalization when resyllabification was possible. It is also interesting to note that our analysis has revealed the same linguistic conditioning (e.g. preceding vowel, following consonant) that appeared to favor vocalization in the analyses discussed in section 2.

Costa (2003) has convincingly argued that l-vocalization has the characteristics of the postlexical rule (Kiparsky, 1988; Labov, 1994), i.e. it is phonetically predictable, has no grammatical conditioning, no exceptions, is phonetically natural (see geometrical representation above), can be understood as a change from below the level of social awareness and produces gradient outputs. ${ }^{14}$ So what we see in our analysis is a truly phrasal phenomenon.

14 One issue that is not yet clearly established is the contradictory fact that /l/-vocalization seems to be neutralizing. We will not be able to discuss this issue at length here in this paper. We understand, however, that postlexical processes are 


\subsection{Transcription and coding procedures}

The second author (Cristine Costa) conducted an auditory analysis of each token of post-vocalic / $/$ / in word final position and the analysis transcribed using a narrow IPA transcription, these transcriptions being re-analyzed by the same author eight months later. A smaller sample of tokens was also analyzed by the first author (Gisela Collischonn), with only tokens in which the transcriptions agreed being used in the VARBRUL analysis. ${ }^{15}$

Tokens for each /1/ were classified according to the following linguistic variables $^{16}$ :

not required to have allophonic effects; that is, they may be neutralizing. Furthermore, preliminary data from a perception experiment indicates that a glide resulting from an underlying lateral may be perceived differently to a glide resulting from an underlying vowel. Other studies (Espiga, 2001) show that there are still phonetic differences between the two glides.

15 Some tokens that had been surpassed in the first transcription were added in this the final set. These represented no more than $10 \%$ of the total.

16 We did not consider in this analysis variables that were not selected as significant in the previous analyses. 
(18)

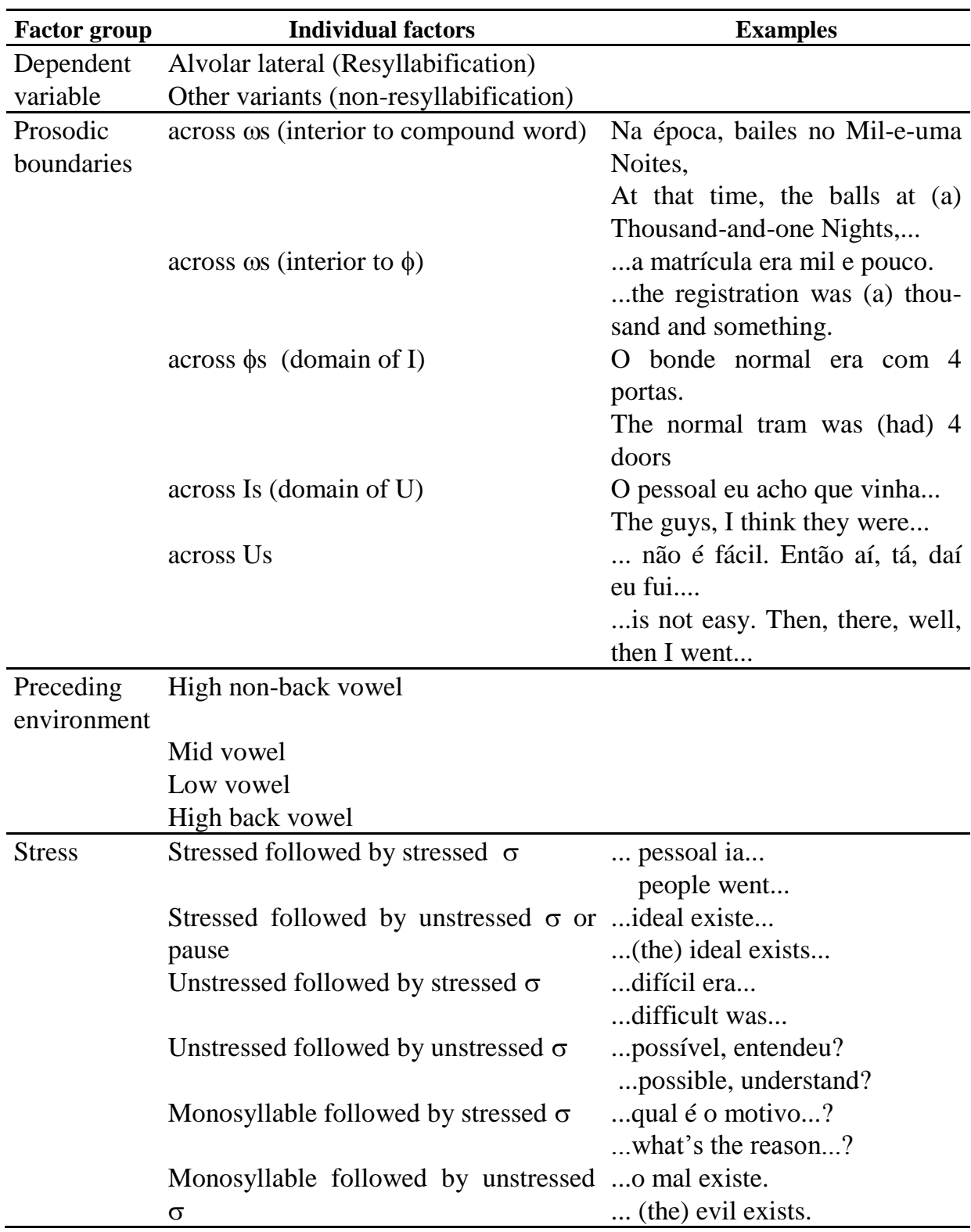

The external variables of sex and age were also considered. A first VARBRUL analysis of 835 tokens revealed that the distribution of the alveolar 
lateral was conditioned by the following context, the Figure below (19) showing that only alveolar laterals occurred when a vowel followed. ${ }^{17}$

(19)

\begin{tabular}{llll}
\hline & & App/Total & Percentage \\
\hline Following & Pause & $0 / 267$ & $0 \%$ \\
environment & Consonant & $1 / 363$ & $0 \%$ \\
& \# plus vowel & $74 / 200$ & $35 \%$ \\
\hline
\end{tabular}

Resyllabification of $/ 1 /$ is reflected in the speech signal by its phonetic properties. The appearance of a semivowel or a velarized lateral points to the absence of resyllabification, since these are not admissible allophones in onset. On the other hand, the results shown above demonstrate that the alveolar lateral is near to non-existent in our BP codas. Thus we have an almost complementary distribution between vocalization and the alveolar lateral and any token of alveolar lateral in the sample may be understood as an instance of resyllabification. With this in mind, we continued with our analysis, considering only the tokens where the following context has a vowel, since these are the true examples where resyllabification is possible. Although this reduced by about $75 \%$ the number of tokens, we still were able to run VARBRUL analyses.

\section{Results}

The factor groups that were selected as significant by the step-up/step-down analysis were (in order): age, prosodic boundary, sex and stress. In the following table (20) we present the linguistic variables with the values for each factor: ${ }^{18}$

17 Contrary to the previous analyses, which had the vocalized variant as its target, this analysis and the following analysis consider the alveolar lateral variant as the application value.

18 The total number of tokens is smaller than 200 because the environments for the across utterances factor had to be eliminated due to knockout (see below). 
(20)

\begin{tabular}{lllll}
\hline Factor group & Individual factors & Applic./Total & Percentage & VARBRUL weight \\
\hline Prosodic & across $\omega$ s (interior to compound word) & $11 / 13$ & $85 \%$ & 0.87 \\
boundaries & across $\omega$ s (interior to $\phi$ ) & $7 / 12$ & $58 \%$ & 0.76 \\
& across $\phi$ s (domain of I) & $37 / 81$ & $46 \%$ & 0.61 \\
& across Is (domain of U) & $19 / 87$ & $22 \%$ & 0.30 \\
& across Us & - & - & - \\
\hline Stress & Monosyllable followed by stressed $\sigma$ & $24 / 27$ & $89 \%$ & 0.93 \\
& Monosyllable followed by unstressed $\sigma$ & $08 / 26$ & $34 \%$ & 0.50 \\
& Stressed followed by stressed $\sigma$ & $14 / 35$ & $40 \%$ & 0.48 \\
& Stressed followed by unstressed $\sigma$ & $22 / 75$ & $29 \%$ & 0.41 \\
& Unstressed followed by unstressed $\sigma$ & $05 / 19$ & $26 \%$ & 0.41 \\
& Unstressed followed by stressed $\sigma$ & $01 / 11$ & $09 \%$ & 0.06 \\
\hline Totals for resyllabification & $74 / 193$ & $30 \%$ & 0.39 \\
\hline
\end{tabular}

As for the internal variables, the prosodic boundaries factor group had to be slightly modified since the across utterances factor presented a knockout value, with none of the seven tokens with that environment presenting resyllabification. This apparently categorical behavior in that environment confirms our expectations, i.e. resyllabification is blocked across utterance boundaries. Below, we present an example:

(21) Essas coisas assim que eu achava legal. $\mathbf{O}$ curso é superbom. "It's things like that which I thought were cool. The course was really good."

On the other hand, we found almost categorical resyllabification in compounds and also high values of resyllabification within $\phi$ s. These two factors were grouped in another run because the number of tokens for each factor was quite low, the results of the run being shown in (22) below.

\begin{tabular}{lllll}
\hline & & Applic./Total & Percentage & $\begin{array}{l}\text { VARBRUL } \\
\text { weight }\end{array}$ \\
\hline Prosodic boundaries & across $\omega$ s (interior to $\phi)$ & $18 / 25$ & $72 \%$ & 0.81 \\
& across $\phi$ s (domain of I) & $37 / 81$ & $46 \%$ & 0.61 \\
& across Is (domain of U) & $19 / 87$ & $22 \%$ & 0.30 \\
\hline
\end{tabular}

Lesser resyllabification happens across $\phi$ boundaries. This factor includes several tokens, like legal assim (pause) "cool like" or difícil aí (pause) "difficult there", which contain an adjective followed by a discursive marker and a pause. Discursive markers might take an I-phrase for their own in a similar 
manner to tag-questions, in other words there would be an intonational phrase boundary between the two words. However, we found that in some cases when the marker appears at the end of the sentence there was no special phrasing for it, and we could hear neither a pause nor a change in intonation nor a special lengthening of the stressed syllable of the word preceding the discursive marker, all of which are predictors of I-phrase boundaries. The only thing which could be detected was a slight increase in the speech rate but this was no different from the normal reduction in the length of poststressed final syllables. Based on the literature regarding BP discursive markers (Silva, 1999) we interpreted these sequences as belonging to the same I-phrase.

The lowest resyllabification values were found across I-phrases, the values for our group of informants being consistant with those published in the literature with the rate of resyllabification being dependent on the boundary that is being crossed.

A second analysis was done to find out whether individuals within the speaker group behaved differently with respect to the prosodic boundary variable. The graph below (23) shows the VARBRUL weights for each informant according to the prosodic boundary.

Resyllabification probability according to informant and prosodic boundary

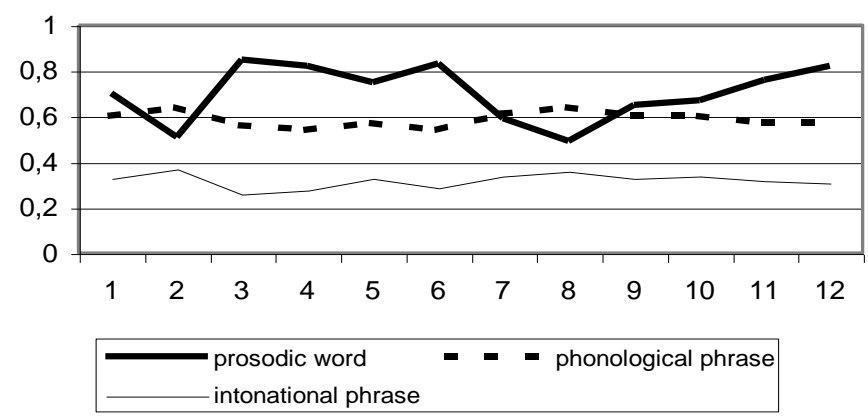

The left side of the graph shows the performances for the male informants (informants 1-6), while the right side shows the performance for the females (informants 7-12). The graph shows that resyllabification is higher within the prosodic phrase, with only two informants (informant 2 and 8) showing slightly different behavior, probably due to uneven distribution of the data. There is a small decrease of resyllabification within the intonational phrase, but the values are still above the 0.50 reference point. The values for resyllabification across intonational phrases are remarkably low, below the 0.50 reference point which shows that resyllabification is disfavored in this environment. 
This graph also shows that the behavior of each individual informant is consistent with the behavior of the whole group. Furthermore, an analysis of the tokens of each informant showed that no informant resyllabified contrary to the group tendency, in other words, no individual resyllabified within the intonational phrase without also resyllabifying within the prosodic phrase. An example is informant 7, who normally shows high values for vocalization except when the environment is favorable for resyllabification (i.e., within prosodic phrase), in which case she consistently shows the alveolar lateral. Across prosodic phrases, informant 7 also variably resyllabifies. At the limit of an Intonational phrase or Utterance, this informant only shows the [w] variant, which fact shows that she never resyllabifies.

As for stress, the analysis shows three distinct patterns, i.e. a monosyllable followed by a stressed vowel is a definitely favoring environment for resyllabification. Adjacent stressed syllables or a monosyllable followed by an unstressed syllable are neutral. When there are no adjacent stressed syllables, resyllabification is disfavored. These findings are consistent with what was detected in a group of speakers from Porto Alegre by Tasca (1999), who found that stressed environments favor alveolar laterals, while unstressed environments favor vocalization. These results are consistent with the postlexical character of the vocalization phenomenon.

The social variables had the following results:

\begin{tabular}{lllll} 
& Group & Applic/Total & Percentage & $\begin{array}{l}\text { VARBRUL } \\
\text { weight }\end{array}$ \\
\hline Age $(\sim$ years) & 60 to 75 & $29 / 41$ & $71 \%$ & 0.84 \\
& 30 to 60 & $36 / 62$ & $43 \%$ & 0.78 \\
& 20 to 30 & $09 / 90$ & $10 \%$ & 0.16 \\
\hline Sex & Male & $53 / 104$ & $51 \%$ & 0.64 \\
& Female & $21 / 89$ & $24 \%$ & 0.34 \\
\hline
\end{tabular}

The values for the age variable were as expected. Since younger informants vocalize more, they show the lowest rates for resyllabification, while the older informants show the highest rates. On the other hand, the values for "sex" are surprising, because before we had not detected in this sample any differences between men and women related to this variable phenomenon. Secondary analyses were conducted to find out whether there was an unexpected interaction between sex and some other independent variable but no interactions were found so we have to accept that female speakers behave differently from male speakers. This result agrees with the findings of Tasca (1999) who studied a group of speakers from Porto Alegre with undergraduate education. Still, this difference must be understood as a difference in overall 
vocalization (women generally tend to vocalize more than men) and not to a difference in the way speakers deal with the prosodic domain restrictions.

\section{Conclusion}

Our analysis shows clear bounding effects at higher prosodic constituents. The values for Utterance boundaries were categorical: no /1/ was resyllabified across an utterance boundary. Unfortunately, we did not have a large amount of tokens where an Utterance final /l/ was immediately followed by a vowel initial utterance, so, this means that results could be in the form of a gradient if we had more data. Notwithstanding, we also detected a strong tendency towards constraining resyllabification of $/ \mathrm{l} / \mathrm{s}$ across I-phrases too, which confirms that resyllabification is sensitive to these higher prosodic boundaries. These results are revealing, since previous research regarding the resyllabification of consonants in BP have not found any blocking. For example, Tenani (2002) has not found any clear propensity towards blocking of consonantal resyllabification in her experiments. Furthermore, Bisol (1999a,b) has detected that resyllabification and vocalic sandhi may apply across higher boundaries. Our results show that there is a tendency towards blocking, albeit not categorical. This means that the speaker is using prosodic information when choosing what variant he uses.

The results indicate that resyllabification seems to be the default option within compounds or phonological phrases. In our analysis, in order to yield a better run, these two domains where grouped into one factor, since the difference between resyllabification internal to compounds as compared to resyllabification across different (not morphologically attached) prosodic words was not very high. This does not mean, however, that our results are not compatible with what is argued in Vigário (2003), i.e., that compound-internal boundaries are different from normal phonological-phrase internal boundaries. Compound internal boundaries seem to be preferred for resyllabification.

On the whole, younger informants vocalize more than older ones. Could that mean that they treat prosodic domains differently, i.e., that the constraints against resyllabification are stricter for the younger generations than for the older ones? The analysis does not support this hypothesis. The results obtained show that, though the input values for resyllabification are different for younger and older people, the same prosodic constraints are valid for all individuals. The increase in /1/ vocalization may lead to a tighter restriction of the possibilities of resyllabification, as a consequence of the fact that the glide resulting from vocalization cannot easily resyllabify as an onset, as was shown before. This may mean that, as a consequence, /1/ resyllabification becomes limited to the domain of the prosodic word in future generations, but for the moment this is no more than speculation. 


\section{Acknowledgments}

We would like to thank Elisa Battisti (Universidade de Caxias do Sul) and CAPES, the Brazilian graduate studies sponsoring agency for help and financial assistance with this research.

\section{References}

Altenhofen, C. V. et alii (2002) Atlas Lingüístico-Etnográfico da Região Sul do Brasil (ALERS) - vol. 2 - Cartas Fonéticas e Morfossintáticas. Porto Alegre: Editora da Universidade/UFRGS; Editora da UFPR; Editora da UFSC.

Bisol, L. (1999a) Os constituintes prosódicos. In Introdução a estudos de fonologia do português brasileiro (L. Bisol, editor). Porto Alegre: EDIPUCRS.

Bisol, L. (1999b) A sílaba e seus constituintes. In Gramática do Português Falado. Vol. VII: Novos Estudos (M. H. M. Neves, editor), pp. 701-742. Campinas: Ed. da UNICAMP.

Brescancini, C. (2002) A fricativa palato-alveolar e sua complexidade. $\mathrm{Ph} . \mathrm{D}$. dissertation. Pontifícia Universidade Católica, Porto Alegre.

Clements, N. \& E. Hume (1995) The internal organization of speech sounds. In The handbook of phonological theory (J. Goldsmith, editor) London: Blackwell.

Costa, C. F. (2003) Fonologia Lexical e controvésria neogramática: análise das regras de montongação de low/ e vocalização de $/ / /$ no $P B$. Porto Alegre: UFRGS.

Dal Mago, D. (1998) O comportamento do /l/ pós-vocálico no Sul do país. Working Papers em Lingüística, 2, 31-44. Florianópolis, 1998.

Espiga, J. (2001) O Português dos Campos Neutrais. Um estudo sociolingüístico da lateral posvocálica nos dialetos fronteiriços de Chuí e Santa Vitória do Palmar. Porto Alegre: PUCRS.

Hayes, B. (1989) The Prosodic Hierarchy in Meter. In Rhythm and Meter (P. Kiparsky \& G. Youmans, editors). Academic Press: Orlando.

Kiparsky, P. (1988) Phonological change. In Linguistics: the Cambridge Survey (F. Newmeyer, editor). Vol 1. Cambridge: CUP.

Labov, W. (1994) Principles of Linguistic Change. Cambridge: Blackwell.

Leite, Y. F., D. M. I. Callou \& J. A. Moraes (2002) Processos de enfraquecimento consonantal no português do Brasil. In Gramática do Português Falado. Campinas: Ed. da UNICAMP, 2002.

Nespor, M. \& I. Vogel (1986) Prosodic Phonology. Dordrecht: Foris.

Oliveira, M. A. \& T. Cristófaro-Silva (2002) Variação do "r" pós-consonantal no português brasileiro: um caso de mudança fonotática ativada por cisão primária. Letras de Hoje 37 (1), 25-47. Porto Alegre.

Peperkamp, S. (1997) Prosodic Words. Den Haag: Holland Academic Graphics.

Quednau, L. (1993) A lateral pós-vocálica no português gaúcho: análise variacionista e representação não-linear. In TELA. Textos em Lingüística Aplicada (V. Leffa, editor). Pelotas: Educat. 2000.

Monaretto, V., L. Quednau \& D. da Hora (1999) As consoantes do português. In Introdução a estudos de fonologia do português brasileiro (L. Bisol, editor). Porto Alegre: EDIPUCRS. 
Sankoff, D. (1988) Variable rule. In Sociolinguistics/Soziolinguistik (U. Ammon, N. Dittmar \& K. J. Mattheier, editors). Berlin: Walter de Gruyter.

Silva, G. M. de O. (1999) Anatomia e fisiologia dos marcadores discursivos não-prototípicos. In Gramática do Português Falado. Vol. VII: Novos Estudos (M. H. M. Neves, editor), pp. 701-742. Campinas: Ed. da UNICAMP.

Tasca, M. (1999) A lateral em coda silábica no Sul do Brasil. Ph.D. dissertation. Porto Alegre: PUCRS.

Tenani, L. (2002) Domínios prosódicos no português do Brasil: implicações para a prosódia e para a aplicação de processos fonológicos. Ph.D. dissertation. Universidade Estadual de Campinas.

Vigário, M. (2003) The Prosodic Word in European Portuguese. Berlin: Mouton de Gruyter.

Walsh, L. (1997). The phonology of liquids. Ph.D. dissertation. University of Massachusetts Amherst.

Wetzels, L. (1997) The Lexical Representation of Nasality in Brazilian Portuguese. Probus 9, 203-232.

\section{Gisela Collischonn \\ UFRGS \\ Brasil}

\section{Cristine Costa \\ UFRGS}

Brasil 